\title{
A política e seus outros: imagens sobre a ação política entre as/os Kaiowá e os/as Guarani
}

\author{
Politics and its others: notes on the transformations in \\ political action among the Kaiowá and Guarani
}

Diógenes Egídio Cariaga ${ }^{1}$

Lauriene Seraguza ${ }^{2}$

DOI: http://dx.doi.org/10.20435/tellus.v17i33.429

\begin{abstract}
Resumo: O contexto atual de vida dos Kaiowá e Guarani em Mato Grosso do Sul é marcado por intensas formas de mobilização e articulação política das famílias como forma de ação para pressionar o Estado em identificar e demarcar seus territórios de habitação tradicional. Neste texto, pretendemos, por meio das nossas reflexões e imagens produzidas através de nossas pesquisas, demonstrar que a vida social kaiowá e guarani é marcada por potentes e múltiplas relações entre eles e seus outros que configuram importantes modos como conceituam sua vida social. As fotos, em conjunto com texto apresentado, procuram dar relevo à ação do pensamento kaiowá como política na mediação e transformação da alteridade.
\end{abstract}

Palavras-chave: cosmopolítica; transformações; Guarani; Kaiowá

Abstract: The Kaiowá and Guarani's current context of life in Mato Grosso do Sul is marked by intense forms of political mobilization and articulation by families as a mode of action to pressure the state into identifying and demarcating their territories of traditional dwelling. In this text we seek, through our reflections and images produced through our researches, show that Kaiowá and Guarani social life is marked by multiple and potent relations between them and their others which configure important modes of conceptualizing social life. The photographs along with the presented text seek to underscore the action of Kaiowá thought as politics in the mediation and transformation of alterity.

Keywords: cosmpolitics; transformations; Guarani; Kaiowá

${ }^{1}$ Universidade Federal de Santa Catarina (UFSC), Florianópolis, Santa Catarina, Brasil.

${ }^{2}$ Universidade de São Paulo (USP), São Paulo, São Paulo, Brasil.

Tellus, Campo Grande, MS, ano 18, n. 35, p. 181-192, jan./abr. 2018 
Desde o final dos anos de 1970, a política nacional brasileira tem sido contrastada com os modos como os indígenas realizam sua vida social, ou seja, como agem politicamente diante das inúmeras formas como o contato realizado pelos não indígenas foi impactando, gradativamente, ao longo dos séculos os diversos contextos indígenas no Brasil, e como tais relações produziram efeitos mútuos. A constituição de um mundo, em que natureza e cultura são domínios separados e hierarquizados, constitui um dos grandes divisores centrais na formulação "nós $x$ eles", como descreveu Latour em Jamais Fomos Modernos (LATOUR, 2005), demonstrando que tais operações não são universais, que a noção monológica sobre o mundo esconde outros mundos povoados por outros seres (humanos e não humanos) que compõem outros modos de ser e conhecer. Segundo o pensador francês, a nossa tarefa é repovoar o mundo a partir das agências outras, sublimadas pela modernidade estabilizada através de grandes divisores, que tende a separar e classificar os modos de existência. Nesse sentido, as perspectivas oriundas desses debates sobre grandes divisores conceituais, na produção dos regimes de conhecimento, se reconectam às discussões de Lévi-Strauss (1976) sobre as qualidades e operações do pensamento em estado selvagem, em que natureza e cultura não são dadas como polos antagônicos, mas como um campo de relações realizadas a partir do pensamento mítico. Para o autor como o bricolage, no plano técnico, a reflexão mítica intelectual pode atingir no plano intelectual, resultados brilhantes e imprevistos (LÉVI-STRAUSS, 1976, p 38).

A nossa intenção neste texto e nas imagens apresentadas produzidas a partir das nossas pesquisas etnográficas, realizadas em interlocução com as famílias kaiowá e guarani que vivem em Mato Grosso do Sul, oriundas de múltiplas situações e contextos de atuação acadêmica e profissional, é dar relevo às formas da ação política como as e os Kaiowá e Guarani refletem sobre as transformações vivenciadas a partir da intensificação do processo de ocupação não indígena no século XX. A criação dos postos indígenas destinados à sedentarização das parentelas que viviam em intensa mobilidade em todo sul do atual MS, região considerada por elas como de habitação tradicional - tekoha retã, acentuou a produção de novas formas de conhecimento e socialidade com vistas a se ajustarem ao aumento da presença dos brancos na região. 


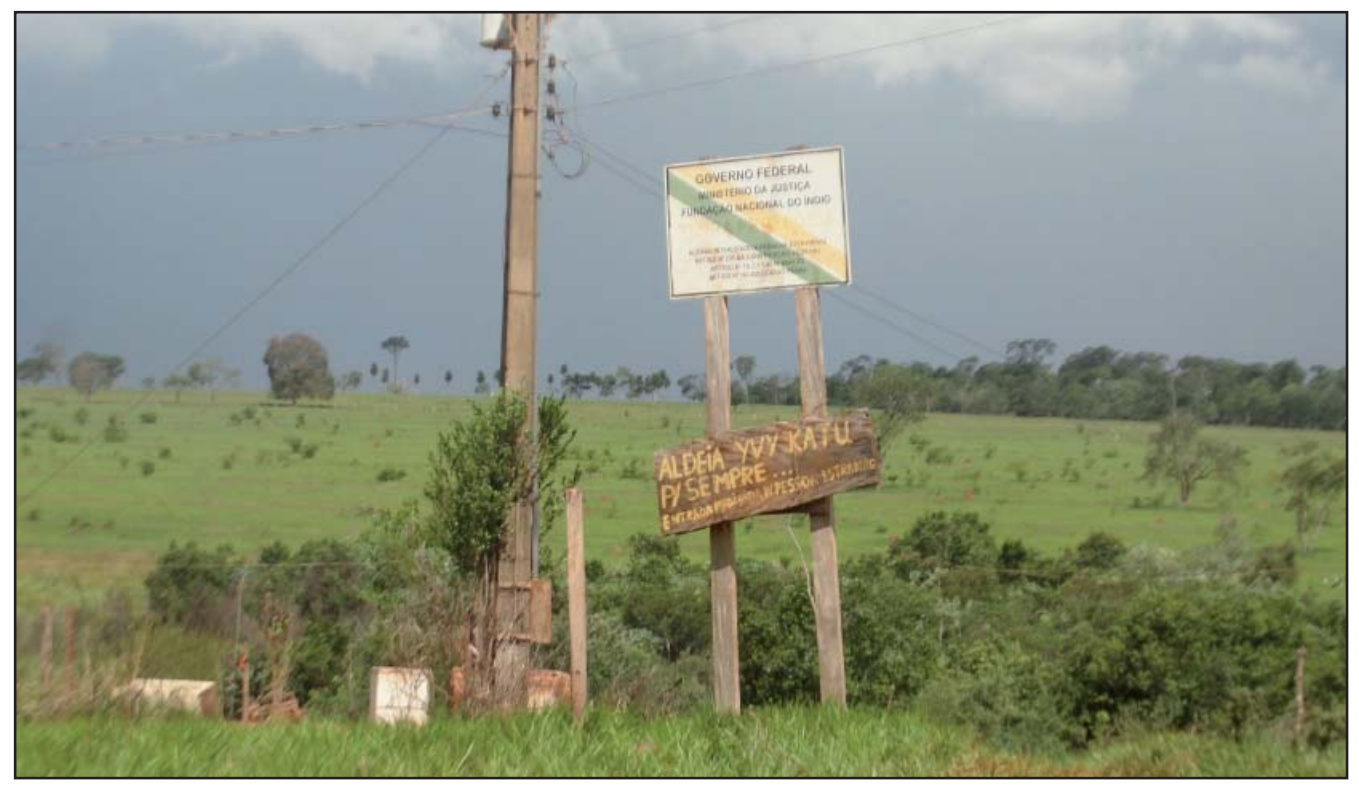

Figura 1 - Placa na entrada da terra indígena das famílias guarani Yvy Katu, Iguatemi, MS, 2013 (Foto de Lauriene Seraguza)

As narrativas kaiowá e guarani contam que, antes da chegada dos brancosyma guare (traduzido como tempo antigo ou tempo ancestral, que remete tanto ao passado mítico onde não havia diferenciação entre humanos e não humanos, quanto ao passado cronológico, na medida que incorporam eventos pré e pós-contato à mitologia e à história), a vida das famílas no tekoha guasu (região tradicionalmente ocupadas por parentelas com relações de afinidade, matrimônio e cooperação), não pode ser entendida como se não houvesse mediações, trocas ou contatos com outros seres.

Em uma conversa com um casal de xamãs e lideranças de uma parentelajekoha, atualmente morando na Aldeia Jaguapiru na Terra Indígena de Dourados, antes da chegada dos brancos, as famílias que tinham laja muito diferentes tinham pouco contato, as famílias se identificavam a partir do local que residiam, que era chefiado por ramõi - avô e uma jarý - avó. Estes reuniam características que adensam características do prestígio da pessoa kaiowá e guarani, como a ação xamânica importante na condução de festas-rituais como a nominação das crianças - mitãnemongaraí, a perfuração dos lábios dos meninos púberes - kunumy pepy e a menarca das meninas - kuña ñemondya ou ikoty, e as festas de cultivo das 
plantas agrícolas, em especial do milho branco (jakaira ou avati morotí) - jerosy (CARIAGA, 2012).

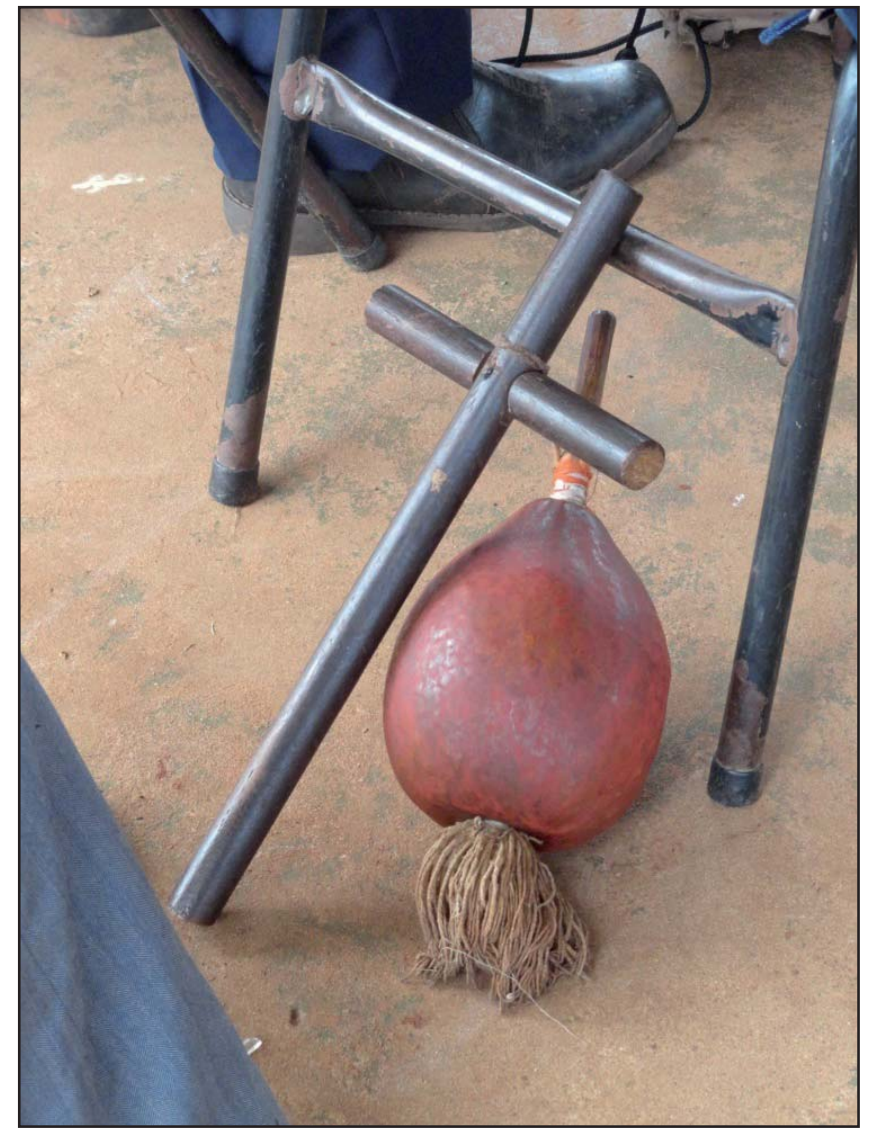

Figura 2 - Kurusu e mbaraká, artefatos portados pelo ñanderu kaiowa, Te'ýikue, Caarapó, MS, 02/2014 (Foto de Diógenes Cariaga)

Cabia a eles também organizar o casamento entre parentelas aliadas e definir sanções morais àqueles que tinham comportamentos inadequados - laja vaí. Contudo esse cenário foi impactado profundamente devido a pressão, assédio e violência do processo de contingenciamento da mobilidade e da imposição em viver nas áreas destinadas à acomodação das parentelas. O efeito da recusa pode ser notado nas narrativas de dispersão, fuga e fissura das parentelas, ou nos termos da fala de uma ñandesý kaiowá na ocasião de uma reunião na Aldeia Jaguapiru, 
em Dourados "karai kuera ojapo ñande ava osarambipá ore tekoha-os brancos e o jeito deles, fez toda nossa gente (ava em lingua guarani quando enunciado pelos nativos refere-se aos grupos) se esparramar na nossa terra".

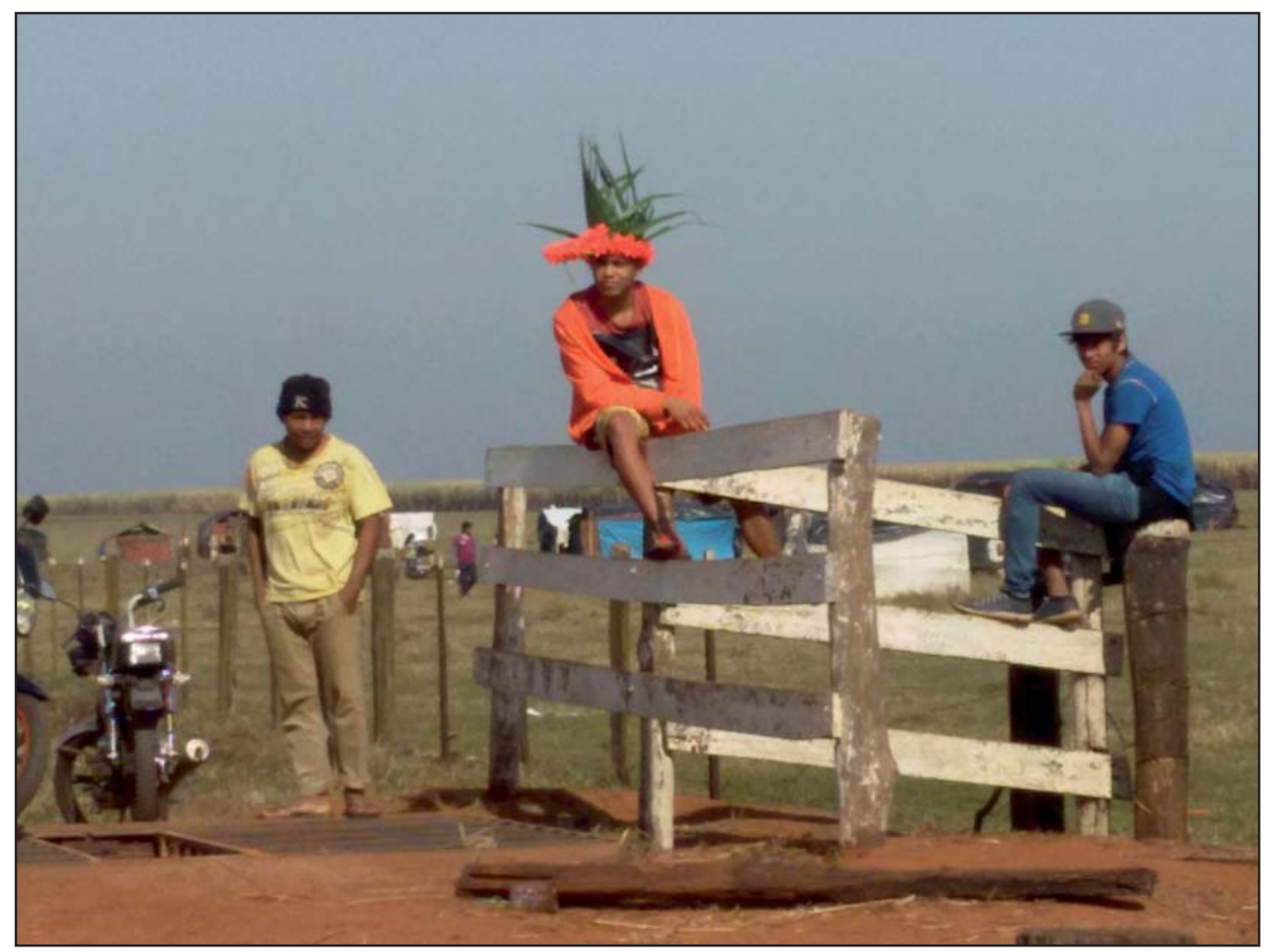

Figura 3 - Retomada em Te'ýikue, Caarapó, MS, 06/2016 (Foto de Lauriene Seraguza)

Nossos exercícios etnográficos (SERAGUZA, 2013 ), (CARIAGA, 2102) somam-se a outros trabalhos que procuram ampliar os conceitos etnográficos acerca da ação política kaiowá e guarani, como os realizados Morais (2016), Crespe (2015), Pimentel (2012) e Pereira (2004), que adensam etnograficamente questões acerca das diferenças nos modos como as famílias kaiowá e guarani,

\footnotetext{
${ }^{3}$ No mês de setembro de 2015 a Fundação Nacional do Índio realizou em Dourados a etapa local da 1 ạ Conferência Nacional de Política Indigenista, reunindo lideranças indígenas para debaterem e formularem proposta para a etapa regional que foi realizada no mês seguinte.
} 
longe de cumprirem a trágica premissa pessimista, acerca da aculturação e do desaparecimento descritas em Schaden (1974), estão ampliando e multiplicando os sentidos e as potências acerca dos seus modos de ser, como estratégias políticas que assegurem, por meio da agência de seus modos de existência, formas políticas de transformar a alteridade em um meio de produção de sua socialidade.

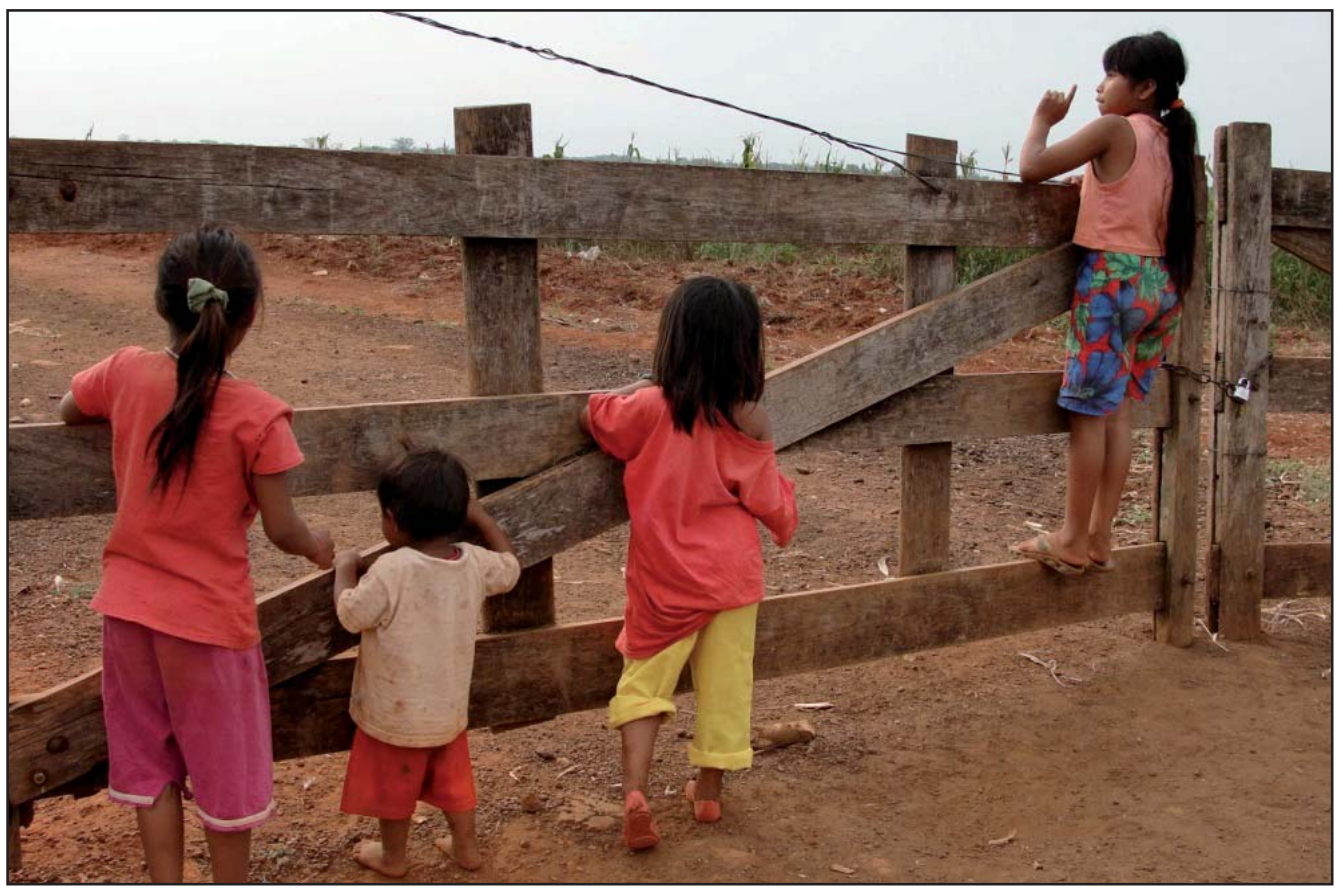

Figura 4-Crianças kaiowá observando o interior da fazenda que haviam retomado após o despejo das famílias kaiowá do Tekoha Laranjeira Ñanderu, Rio Brilhante, MS, 09/2009 (foto de Lauriene Seraguza)

A cosmopolítica entre os e as Kaiowá e Guarani é atravessada pelas rezas e cantos dos ñanderu e ñandesy (rezador e rezadora, ou xamãs). As suas lutas são acompanhadas pelas rezas e cantos que são entoadas numa negociação cósmica, visam à alegria, e está conectada com o teko porã, o bom modo de ser kaiowá e guarani, que depende exclusivamente de poder viver em suas terras ancestrais (SERAGUZA, 2013). O conceito de teko porã aponta para os modos como as relações entre os modos de vida das pessoas estão diretamente associados com questões que dizem respeito à mitologia, cosmologia e xamanismo. 


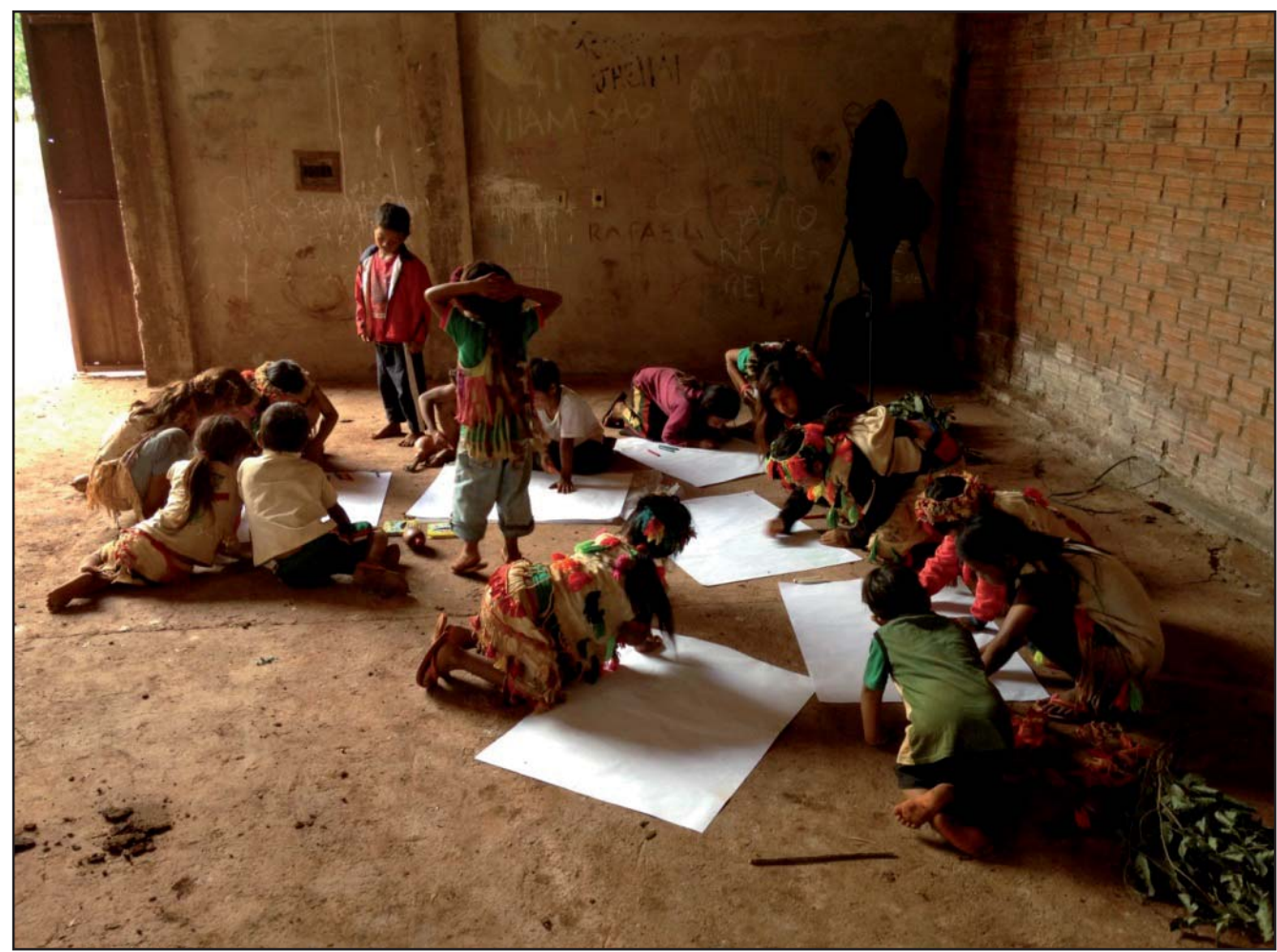

Figura 5 - Crianças kaiowá na retomada Guaiviry, Aral Moreira, MS, 03/2016 (Foto de Diógenes Cariaga)

Nesse sentido, teko porã opera mais com uma constelação conceitual do que com um conceito, porque se trata de desdobrarmos e deslocarmos os sentidos da tradução do campo da 'vida religiosa guarani', como já advertiu Viveiros de Castro (1987), para se compreender partes que compõem relações, ou seja, não se trata de tomar uma tradução imediata ou como tópicos, mas procura descrever como operam uns em relação ao outro (STRATHERN, 2011), explorando a potência dos conceitos nativos (ZEA, 2016; VIVEIROS DE CASTRO, 2002b) 


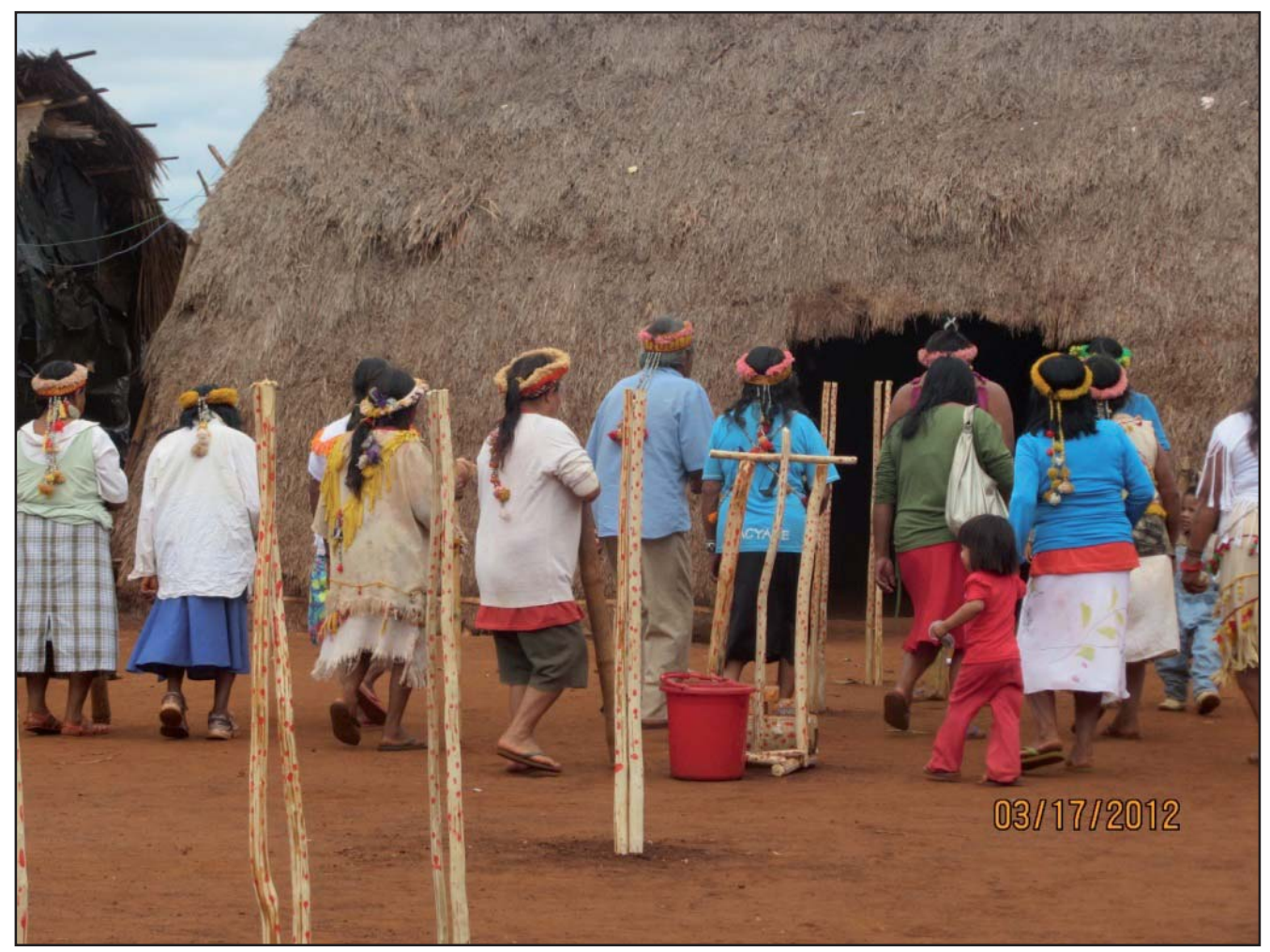

Figura 6 - Jeroky, Ita'ýkaagwyrusu, Douradina, MS, 2012 (Foto de Diógenes Cariaga)

A proposição etnográfica de Pereira (2004), que dá ênfase à relacionalidade, nos guia em direção à reflexão sobre o desafio colocado em discorrer sobre termos como "tradicional e antigo", assim como "moderno e novo", que se articulam aos princípios kaiowá e guarani de dispersão (ou abertura) do sistema social ao campo de afins potenciais ${ }^{4}$ - pavêm, aos mecanismos e operadores de concentração (fechamento) do que eles chamam de nosso sistema-ore reko. ${ }^{5}$

\footnotetext{
${ }^{4} \mathrm{~A}$ afinidade potencial é um conceito central às formulações de Viveiros de Castro no decorrer de sua proposição de uma teoria etnográfica sobre as relações ameríndias. Na coletânea "A inconstância da alma selvagem e outros ensaios em antropologia" (VIVEIROS DE CASTRO, 2002a), retoma e amplia discussões do conceito.

${ }^{5}$ As palavras em itálico referem-se a termos nativos que entendemos como operadores pelos quais os Kaiowá e Guarani refletem sobre as inovações e transformações no sistema social.
} 


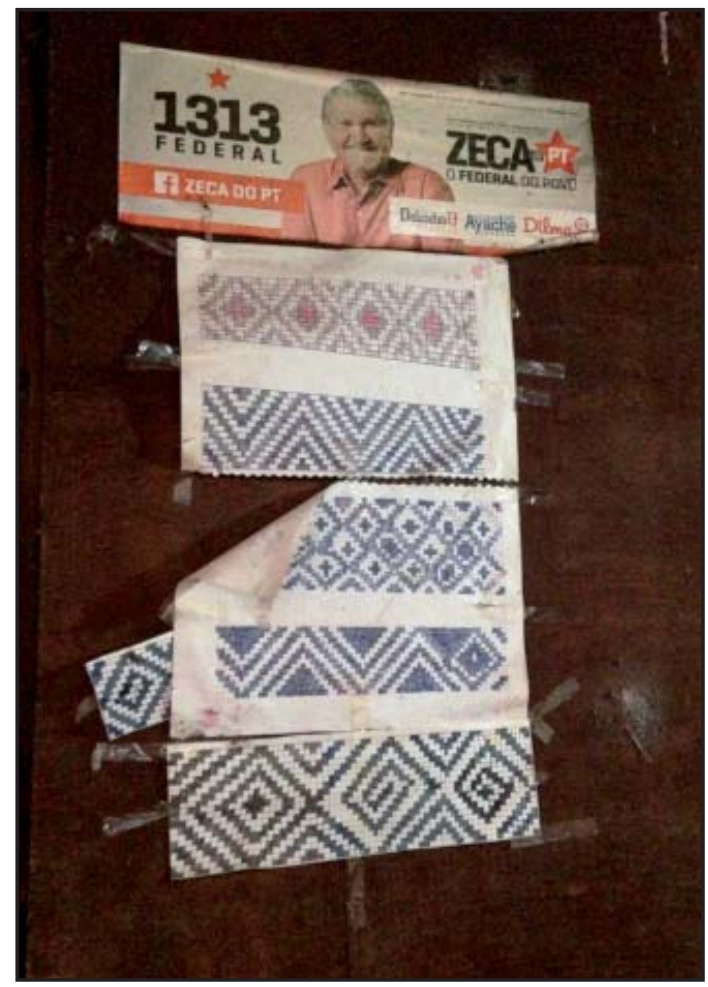

Figura 7 - Parede de uma casa na retomada Tekoha Ita'ýkaagwyrusu, Rio Brilhante, MS, 04/2016 (Foto de Diógenes Cariaga)

Estamos interessados em pensar sobre os operadores da diferença propostos por Lévi-Strauss (1993), acerca do movimento transformacional-relacional instituído pelo dualismo em desequilíbrio perpétuo inerente à abertura ao outro (ou vice-versa), tomando como veículos de produção de redes, momentos em campo transformados em dados etnográficos imagéticos no texto, como iremos demonstrar a seguir. Nossa intenção é demonstrar que os modos de existência kaiowá e guarani são paisagens densamente povoadas por múltiplas agências, capazes de criar e inovar conhecimentos, narrativas, posições relacionais, no intuito de dar relevo ao que temos entendido a respeito da presença dos brancos, enquanto mais uma das relações, que, nos dias atuais, despendem muitas reflexões entre os Kaiowá e Guarani devido à assimetria nas mediações políticas das diferenças, partindo das formas nativas de conceituar tais questões. 


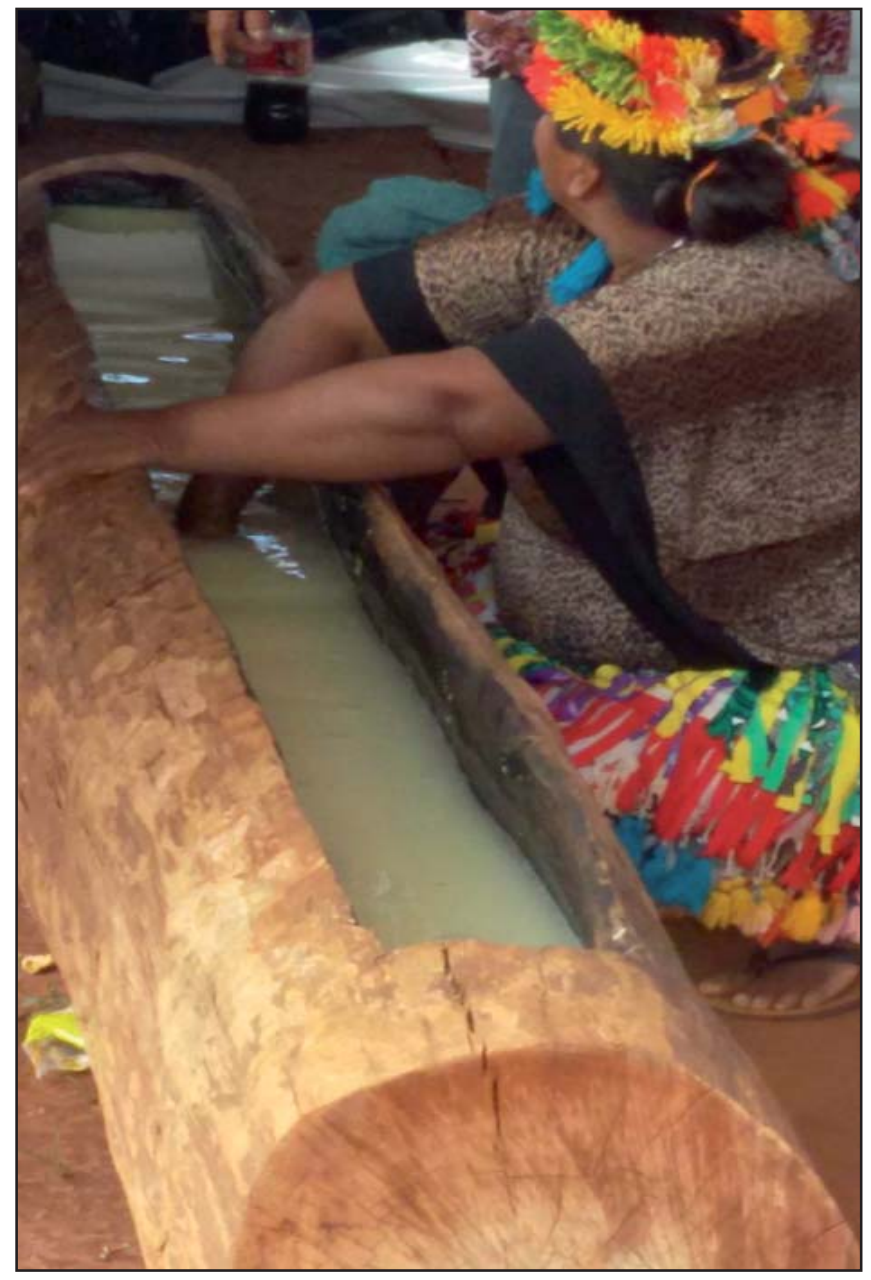

Figura 8 - Mulher fazendo a bebida de milho branco fermentada, chicha ou kaaguy, Reserva Indígena Amambai, MS, 2015 (Foto de Lauriene Seraguza)

\section{REFERÊNCIAS}

CARIAGA, Diógenes E. As transformações nos modos de ser criança entre os Kaiowa em Te'ýikue - Caarapó/MS (1950-2010). 2012. Dissertação (Mestrado em História - História Indígena) - Universidade Federal da Grande Dourados, Dourados, MS, 2012. 
CRESPE, Aline Castilho. Mobilidade e temporalidade Kaiowá: do tekohá à reserva, do tekoharã ao tekoha. 2015. Tese (Doutorado em História - História Indígena) - Universidade Federal da Grande Dourados, Dourados, MS, 2015.

LATOUR, Bruno. Jamais fomos modernos. 4. ed. Rio de Janeiro: Editora 34, 2005.

LÉVI-STRAUSS, Claude. História de Lince. São Paulo: Companhia das Letras, 1993. . O pensamento selvagem. Rio de Janeiro: Companhia Editora Nacional, 1976.

LUCIANI, José A. Kelly. Sobre a antimestiçagem. Tradução de Nicole Soares Pinto, Levindo Pereira e Marcos de Almeida Matos. Curitiba: Species - Núcleo de Antropologia Especulativa; Florianópolis: Cultura e Bárbarie, 2016.

MORAIS, Bruno M. Do corpo ao pó: crônicas da territorialidade Kaiowá e Guarani nas ajacências da morte. 2016. Dissertação (Mestrado em Antropologia Social) - Universidade de São Paulo, São Paulo, SP, 2016.

PEREIRA, Levi M. Imagens Kaiowá do sistema social e seu entorno. 2004. Tese (Doutorado em Antropologia Social)- Universidade de São Paulo, SP, 2004.

PIMENTEL, Spensy K. Elementos para uma teoria política kaiowá e guarani. 2012. Tese (Doutorado em Antropologia Social) - Universidade de São Paulo, SP, 2012.

SAHLINS, Marshall. Ihas de História. Rio de Janeiro: Jorge Zahar Editor, 1990.

SCHADEN, Egon. Aspectos fundamentais da cultura Guarani. São Paulo: EPU/EDUSP, 1974. [1954, 1. ed.].

SERAGUZA, Lauriene. Cosmos, corpos e mulheres Kaiowa e Guarani: de aña à kuña. 2013. 196f. Dissertação (Mestrado em Antropologia Sociocultural) - Universidade Federal da Grande Dourados, Dourados, MS, 2013.

STRATHERN, Marilyn. Sharing, stealing and borrowing simultaneously. In: STRANG, Veronica and BUSSE, Mark (Ed.). Ownership Appropriation. Oxford, New York: Berg Publisher, 2011. p. 23-42.

VIVEIROS DE CASTRO, Eduardo. A inconstância da alma selvagem e outros ensaios em Antropologia. São Paulo: Cosac \& Naify, 2002a.

. O nativo relativo. Mana - Estudos em Antropologia Social, Rio de Janeiro, v. 8, n. 1, p. 113-48, 2002b.

- Nimuendaju e os Guarani. In: NIMUENDAJU, Curt Unkel. As lendas da criação e destruição do mundo como fundamentos da religião dos Apapocúva-Guarani. São Paulo: HUCITEC/EDUSP, 1987. p. xvii-xxxviii. (Coleção Ciências Sociais). 
ZEA, Evelyn M. Tradução como iniciação. Cadernos de Tradução, Florianópolis, v. 36, n. 3, p. 192-212, set./dez. 2016.

\section{Sobre os autores:}

Diógenes Egídio Cariaga: doutorando em Antropologia Social pela Universidade Federal de Santa Catarina, mestre em História (História Indígena) pelo PPGH/ UFGD e bacharel em Ciências Sociais pela UFMS. Atualmente desenvolve pesquisa sobre a ação política ameríndia entre os Kaiowá no Mato Grosso do Sul, com apoio financeiro do CPNq, INCT Brasil Plural, vinculados a Núcleo de Estudos de Povos Indígenas. Realizado consultorias, assessorias e trabalhos técnicos junto à organizações governamentais e não governamentais, assim como a atuação em laudos e perícias antropológicas. E-mail: didioaems@gmail.com

Lauriene Seraguza: doutoranda em Antropologia Social no PPGAS/USP, mestre em Antropologia Sociocultural pela UFGD e licenciada em Letras. Bolsista FAPESP, Processo n. 2017/09129-7. E-mail: seraguzza@gmail.com

Recebido em 10 de novembro de 2017

Aprovado para publicação em 31 de janeiro de 2018 